\title{
Yield and Nutritional Value of Swiss Chard Grown for Summer and Autumn Harvest
}

\author{
Eugeniusz Kołota \\ Department of Horticulture \\ University of Environmental and Life Sciences Wroclaw \\ Pl. Grunwaldzki 24A, 50 - 363 Wroclaw, Poland \\ Tel: 48-71-320-1732Ｅ-mail: eugeniusz.kolota@up.wroc.pl \\ Katarzyna Adamczewska-Sowińska (Corresponding author) \\ Department of Horticulture \\ University of Environmental and Life Sciences Wroclaw \\ Pl. Grunwaldzki 24A, 50 - 363 Wroclaw, Poland \\ Tel: 48-71-320-1732Ｅ-mail: katarzyna.a-sowinska@up.wroc.pl \\ Kamila Czerniak \\ Department of Horticulture \\ University of Environmental and Life Sciences Wroclaw \\ Pl. Grunwaldzki 24A, 50 - 363 Wroclaw, Poland
}

Tel: 48-713201732

\begin{abstract}
Seeds of 5 Swiss chard cultivars were sown on 20 April or 15 July, and single harvest of leaf rosettes was conducted on early July or half of October, respectively. Results of the study indicate the possibility of growing the Swiss chard both in spring and autumn term, but yield of leaves obtained in the spring was double as high as in the autumn cultivation. Among tested cultivars Green White Ribbed and Bresanne provided the highest, while Vulcan the lowest yield in spring growing. However, the choice of cultivar had not a significant meaning in autumn season cultivation. Spring season culture caused a significant reduction of nitrates accumulation and was preferable for the content of $\mathrm{P}$, while autumn term for dry matter, $\mathrm{K}$ and $\mathrm{Ca}$ in both parts of leaves, vitamin $\mathrm{C}$ in leaf blades, and $\mathrm{Mg}$ in petioles. Irrespective of the term of growing and cultivar, leaf blades contained higher level of dry matter and $\mathrm{Mg}$, while leaf petioles - nitrates, potassium and calcium.
\end{abstract}

Keywords: Swiss chard, Cultivars, Growing time, Yield, Nutritional value

\section{Introduction}

One of the major problems in vegetable culture is to assure for each species an economically profitable and good quality crop for as long period as possible. Swiss chard is being characterized as a valuable vegetable species with short vegetation period, ready for harvest in about 60 to 70 days after planting (Swiader et al.,1992). For this reason it can be recommended for growing as forecrop or aftercrop in crop rotation in order to extend the period of its supply to the fresh market since early summer to autumn months.

Currently, Swiss chard is a minor crop in Poland, grown mostly in home gardens, and enlargement of its production on commercial scale may result in increment of consumption the leafy vegetables during summer. Some another vegetable species belonging to this group like spinach cannot be grown during summer months because of bolting and poor quality of the crop (Skapski et al., 1995). In contrast, premature flowering as the response to long day and high temperature conditions does not happen in growing of the most Swiss chard cultivars (Czerniak, 2008).According to the research data obtained with different vegetable species, sowing time may have a great influence not only on the yield but also a nutritional value of the crop. In most cases leafy vegetables like parsley, lamb's lettuce, spinach, butter head lettuce or cichory grown is spring season provided 
significantly higher yields with lower content of dry matter, vitamin $\mathrm{C}$, while higher amounts of sugars (Bohrer 1990; Drews et al.,1995; Adamczewska-Sowińska and Kołota, 2000; Majkowska-Gadomska and Wierzbicka, 2005). The quality of autumn harvested leafy vegetables may be diminished by a high nitrates accumulation. Foliage crops invariably contain a lot of nitrates, even when grown at reasonable nitrogen fertilization (Greenwood and Hunt, 1985) theire amounts may be considerably enhanced in growing in poor light conditions (Drews et al.,1995; Jaworska and Kmiecik, 1999; Kozik, 2006, Francke and Majkowska -Gadomska, 2008).

The aim of the present study was to evaluate the suitability of some Swiss chard cultivars for early summer and autumn cropping.

\section{Material and methods}

Field experiment was conducted in 2005-2007 in Vegetable and Ornamental Plants Research Station located near Wroclaw on a sandy clay soil with pH 6.9 and organic matter content 1.8\%. Seeds of Swiss chard Lukullus, Green White Ribbed, Vulcan, Bresanne and Green Silver cultivars were sown on plots on 20 of April or 15 of July in spacing $45 \times 25 \mathrm{~cm}$. At the stage of 2-4 leaves the seedlings were thinned to one per spot. The experiment was established in two factorial design in four replications and a plot area $5,4 \mathrm{~m}^{2}(3 \times 1.8 \mathrm{~m})$.

Available forms of phosphorus and potassium were raised up by early spring fertilization to $80 \mathrm{mg} P$ and $200 \mathrm{mg}$ $\mathrm{K}$ per $1 \mathrm{dm}^{3}$ of the soil by using triple superphosphate and potassium chloride. Nitrogen was supplied in a split dose, $100 \mathrm{~kg} \mathrm{~N} \cdot \mathrm{ha}^{-1}$ as a preplant fertilization and $50 \mathrm{~kg} \mathrm{~N} \cdot \mathrm{ha}^{-1}$ as a top dressing, shortly after thinning the plants.

Harvest of leaves and petioles was conducted in early July from spring sowing and in half of October from summer sowing. It was arranged in a similar manner as in commercial plantations, by cutting off all leaves above the growing point. During harvest there were collected the samples of edible parts for chemical analysis of leaf blades and petioles. There was evaluated the content of dry matter (drying to the constant weight at $105^{\circ} \mathrm{C}$ ), nitrates (potentiometrically), $\mathrm{P}$ and $\mathrm{Mg}$ (colometrically), $\mathrm{K}$ and $\mathrm{Ca}$ (photometric method), and additionally vitamin $\mathrm{C}$ in leaf blades (Tillman's method).

The results were evaluated statistically using analysis of variance. The least significant differences were calculated by Tukey test at $\alpha=0,05$.

\section{Results and discussion}

Data of the experiment shown in Table 1 as means for three years of the study indicate high differences in marketable yield of Swiss chard in summer and autumn harvest. Significantly higher yields of all tested cultivars obtained in spring growing $\left(61.74 \mathrm{t} \cdot \mathrm{ha}^{-1}\right)$ in comparison to the autumn season $\left(30.64 \mathrm{t} \cdot \mathrm{ha}^{-1}\right)$ may be explained by better solar radiation conditions. Similar response of yielding to the growing term was also observed in butterhead lettuce production (Drews et al., 1995; Skapski et al., 1995) leafy parsley (Bohrer, 1990) and dill (Dyduch and Kawecka, 2003).

Among cultivars compared in the trial Green White Ribbed, Bresanne and Green Silver considerably overyielded the others in spring cultivation, but not significant differences were found in autumn growing. The important quality characteristic of Green White Ribbed cv.appeared to be the lowest amounts of nitrates accumulation in leaf blades und petioles, independently on growing conditions. Vulcan, which produced considerably lower yield of leaves than the other tested cultivars in the case of growing for summer harvest seem to be attractive for home gardens cultivation because of the red colour leaf petioles and green to purple colour of the blades. The unfavorable feature of this cultivar was a high tendency for premature flowering, irrespective of the term of growing. Widely grown in Poland Lukullus cv. which is appreciated for its curled, plane green leaves contained high amounts of dry matter while low $\mathrm{P}$ and $\mathrm{Mg}$ level in edible parts.

On the average, dry matter content in leaf blades was almost double as high as in the petioles. Plants grown in autumn season contained higher amounts of dry matter and for this reason may be recognized as more suitable for processing, then produced in spring months.

Vitamin C was evaluated only in leaf blades of tested cultivars, except Vulcan. It was found that Swiss chard may be considered as a rich source of this compound, especially in autumn growing (Table 2). Generally, its content was equal to $37.15 \mathrm{mg} \cdot 100 \mathrm{~g}^{-1}$ fresh weight at summer harvest and increased to $60.12 \mathrm{mg} \cdot 100 \mathrm{~g}^{-1}$ in the autumn. Similar level of vitamin C concentration in this vegetable crop within a range of 43.8 and $59.8 \mathrm{mg}$. $100 \mathrm{~g}^{-1}$ f.w. depending on the nitrogen rate was found by Dzida and Pitura (2008).

Nitrates content in Swiss chard was generally high like in other leafy vegetable species and showed significant differences under influence of the term of growing, cultivar as well as part of the plant taken for chemical analysis. Like in the studies conducted with butterhead lettuce, spinach and leafy cichory (Drews et al., 1995; 
Jaworska and Kmiecik, 1999; Kozik, 2006; Francke and Majkowska-Gadomska, 2008] plants grown in spring months contained lower amounts of $\mathrm{NO}_{3}-\mathrm{N}$ in leaf blades $\left(366 \mathrm{mg} \cdot \mathrm{kg}^{-1}\right.$ f.w. $)$ and petioles $\left(1515 \mathrm{mg} \cdot \mathrm{kg}^{-1}\right.$ f.w.) in comparison to the autumn growing (1821 and $2907 \mathrm{mg} \cdot \mathrm{kg}^{-1} \mathrm{f}$.w). High differences in nitrates accumulation due to the term of growing may be explained as the result of differentiated light conditions, namely shorter day length and lower light intensity before harvest conducted in October which highly retards growth rate of plants. Similar influence of poor light conditions on nitrates concentration was observed by Cantliffe $(1972,1973)$ in red beet and the effects were most pronounced at heavy nitrogen fertilization. Irrespective of the term of growing, the nitrates content in petioles was much higher than in the blades and this is in agreement with the work of Maynard et al. [1976], Mengel and Kirkby (1982), Fereira (1997) and Kmiecik et al. (2005). In research conducted by Caranca et al. (2001) the amounts of this component in spinach petioles was even four times greater than in blades and similar differences were also observed in Swiss chard grown in spring season, while in much lower degree during the autumn.

Mineral contents (Table 3 and 4) were usually dependent on the cultivar but to much higher extent on the leaf part and growing period. Phosphorus content in both leaf parts as well as magnesium in leaf blades was significantly higher in spring cultivation due to more preferable soil temperature condition in the period proceeding the harvest in comparison to the cultivation in autumn. The opposite results were obtained for potassium and calcium concentration. Leaf blades contained lower amounts of calcium and potassium while higher concentration of magnesium as well as phosphorus in spring culture than petioles of Swiss chard.

\section{References}

Adamczewska-Sowińska, K. \& Kołota, E. (2000). Ocena plonowania i wartości odżywczej kilku odmian roszponki w uprawie na zbiór wczesnowiosenny i jesienny. Roczniki AR w Poznaniu, Ogrodn., 3: 205-209.

Bohrer, M.E. (1990). Einfluss von Erntetermin und Nacherntebehandlung auf Ertrag und Qualitätsbestimmende Eigenschaften von Blattpetersiliensorten. Gemüse, 1: 38.

Carranca, C., Soares da Silva, A., Fernandes, M., \& Verela, J. (2001). ${ }^{15}$ N Fertilizer Use Efficiency by Spinach Grown under Portuguese Field Conditions. Acta Hort., 563: 67-72.

Cantliffe, D.J. (1972). Nitrate accumulation in vegetable crops as affected by photoperiod and light duration. $J$. Amer. Soc. Hort. Sci., 97: 414-418.

Cantliffe, D.J. (1973). Nitrate accumulation in table beets and spinach as affected by nitrogen, phosphorus, and potassium nutrition and light intensity. Agron. J., 65: 563-565.

Czerniak, K. (2008). Wpływ wybranych czynników agrotechnicznych na plonowanie i wartość odżywczą buraka liściowego (Beta vulgaris L. var. cicla L.). PhD thesis, 127 pp.

Drews, M., Schonhof, I., \& Krumbein, A. (1995). Nitrat-, Vitamin C, ß-Karotin und Zuckergehalt von Kopfsalat im Jahresverlauf beim Anbau im Gewächshaus (Lactuca sativa L.). Gartenbauwiss., 60 (4): 180-187.

Dzida, K., \& Pitura, K. (2008). The influence of varied nitrogen fertilization on yield and chemical composition of Swiss chard (Beta vulgaris var. cicla L.). Acta Sci.Pol.Hortorum Cultus, 7(3): 15-24.

Dyduch, J., \& Kawecka, A. (2003). Plonowanie odmian kopru ogrodowego (Anethum graveolens L.) w zależności od terminów siewu. Folia Horticulture, Suplement (2003/1): 99-101.

Ferreira, J. (1997). Nitratos, agricultura biológica e qualidade. A Joaninha, 56: 16-23.

Francke, A., \& Majkowska-Gadomska, J. (2008). Effect of planting date and method on the chemical composition of radicchio heads. J. Elementol., 13(2): 199-204.

Greenwod, D.J., \& Hunt, J. (1985). Effect of Nitrogen Fertilizer on the Nitrate Contents of Field Vegetables Grown in Britain. J. Sci. Food Agric., 37: 373-383.

Jaworska, G., \& Kmiecik, W. (1999). Content of selected mineral compounds, nitrates III and V, and oxalates in spinach ( Spinacia oleracea L.) and new zeland spinach (Tertragonia expansa Murr.) from spring and autumn growing seasons. Electronic Journal of Polish Agricultural Universities. Food Science and Technology, Vol 2.

Kmiecik, W., Lisiewska, Z., \& Gębczyński, P. (2005). The level of nitrates and oxalates in different usable parts of dill (Anethum graveolens L.) depending on plant height. Acta Scientiarum Polonorum, Technologia Alimentaria, 4(1): 93-102.

Kozik, E. (2006). Wpływ terminu zbioru oraz nawożenia azotem i potasem na zawartość azotanów w sałacie uprawianej w szklarni. Acta Agrophysica, 7 (3): 633-642. 
Majkowska -Gadomska, J., \& Wierzbicka, B. (2005). Wpływ terminu uprawy i sorbentów na plon i zawartość wybranych składników pokarmowych w liściach sałaty. Zesz.Nauk.AR we Wrocławiu, Rol., 515: 339-345.

Maynard, D.N., Barker, A.V., Minotti, P.L., \& Peck, N.H. (1976). Nitrate accumulation in vegetables. Advances in Agronomy, 28: 71-118.

Mengel K., \& Kirkby E.A. (1982). Principles of Plant Nutrition. $3^{\text {rd }}$ edition, International Potash Institute Publ., Switzerland, pp. 525-542.

Skapski, H.,Gajc-Wolska, J., \& Odziemkowski, S. (1995). Wpływ odmiany i terminu uprawy na plonowanie wybranych gatunków warzyw liściowych. Ogólnopolska Konferencja Naukowa, Nowe technologie, a jakość plonu warzyw" (20-21 czerwca 1995): 13-18.

Swiader, J.M., Ware, G.W., \& Mccollum, J.P. (1992). Producing vegetable crops. Danville, Illinois, USA: Interstate. Pubblishers Inc.

Table 1. Yield and dry matter content in Swiss chard in relation to cultivar ant term of growing (mean for 2005-2007)

\begin{tabular}{lcccccccccc}
\hline \multirow{2}{*}{ Cultivar } & \multicolumn{3}{c}{ Yield $\left(\mathrm{t} \cdot \mathrm{ha}^{-1}\right)$} & \multicolumn{4}{c}{ Dry matter } & \multicolumn{1}{c}{$(\%)$} \\
\cline { 2 - 10 } & $\mathrm{S}$ & $\mathrm{A}$ & mean & \multicolumn{3}{c}{ blades } & \multicolumn{4}{c}{ petioles } \\
\cline { 5 - 11 } & & & & $\mathrm{S}$ & $\mathrm{A}$ & mean & $\mathrm{S}$ & $\mathrm{A}$ & mean \\
\hline Lukullus & 57.44 & 29.18 & 43.31 & 12.38 & 14.90 & 13.64 & 7.81 & 9.54 & 8.68 \\
Green White Ribbed & 74.82 & 31.37 & 53.10 & 11.02 & 13.62 & 12.32 & 5.92 & 8.22 & 7.07 \\
Vulcan & 41.06 & 28.37 & 34.72 & 11.88 & 14.09 & 12.99 & 7.24 & 9.21 & 8.22 \\
Bresanne & 71.81 & 31.87 & 51.84 & 11.66 & 13.76 & 12.71 & 6.91 & 7.74 & 7.33 \\
Green Silver & 65.56 & 32.42 & 47.99 & 11.16 & 13.45 & 12.31 & 6.77 & 7.97 & 7.37 \\
\hline \multicolumn{1}{c}{ Mean } & 61.74 & 30.64 & 46.19 & 11.62 & 13.96 & 12.79 & 6.93 & 8.54 & 7.73 \\
\hline S - spring growing & A- autumn & & & & & & & \\
0.05 for: & & & & & & & & & \\
growing & & & 4.47 & & & 0.50 & & & 0.57 \\
& & & 7.07 & & & 0.78 & & & 0.90 \\
ion & & & 9.98 & & & n.s. & & n.s.
\end{tabular}

Table 2. Vitamin C and nitrates content in Swiss chard in relation to cultivar and term of growing ( mean for 2005-2007)

\begin{tabular}{|c|c|c|c|c|c|c|c|c|c|}
\hline \multirow[t]{3}{*}{ Cultivar } & \multicolumn{3}{|c|}{$\begin{array}{c}\text { Vitamin C (mg } 100 \mathrm{~g}^{-1} \\
\text { f.w.) }\end{array}$} & \multicolumn{6}{|c|}{ Nitrates $\left(\mathrm{NO}_{3} \cdot \mathrm{kg}^{-1}\right.$ f.w. $)$} \\
\hline & \multicolumn{2}{|c|}{ blades } & \multirow[t]{2}{*}{ mean } & \multicolumn{3}{|c|}{ blades } & \multicolumn{3}{|c|}{ petioles } \\
\hline & $\mathrm{S}$ & A & & $\mathrm{S}$ & A & mean & $\mathrm{S}$ & A & mean \\
\hline Lukullus & 34.03 & 64.60 & 49.32 & 361 & 1487 & 924 & 1743 & 3097 & 2420 \\
\hline White & 38.86 & 58.26 & 48.56 & 296 & 1376 & 836 & 1679 & 2638 & 2158 \\
\hline Ribbed & - & - & - & 341 & 1495 & 918 & 2029 & 3177 & 2603 \\
\hline Vulcan & 38.10 & 55.38 & 46.74 & 418 & 1588 & 1003 & 1951 & 2998 & 2474 \\
\hline Bresanne & 37.62 & 62.24 & 49.93 & 416 & 1628 & 1022 & 1702 & 2627 & 2164 \\
\hline \multicolumn{10}{|l|}{ Green Silver } \\
\hline Mean & 37.15 & 60.12 & 48.64 & 366 & 1515 & 941 & 1821 & 2907 & 2364 \\
\hline S - spring growing & \multicolumn{2}{|c|}{ A- autumn } & & & & & & & \\
\hline $\begin{array}{l}\mathrm{LSD} \alpha=0.05 \text { for: } \\
\text { term of growing }\end{array}$ & & & 2.56 & & & 77 & & & 127 \\
\hline cultivar & & & n.s. & & & 122 & & & 201 \\
\hline interaction & & & 5.11 & & & n.s. & & & n.s. \\
\hline
\end{tabular}


Table 3. Phosphorus and potassium content in Swiss chard in relation to cultivar and term of growing (mean for 2005-2007)

\begin{tabular}{|c|c|c|c|c|c|c|c|c|c|c|c|c|}
\hline \multirow{3}{*}{ Cultivar } & \multicolumn{7}{|c|}{ Phosphorus (\% d·m.) } & \multicolumn{5}{|c|}{ Potassium $(\% \mathrm{~d} \cdot \mathrm{m})}$. \\
\hline & \multicolumn{3}{|c|}{ blades } & \multicolumn{3}{|c|}{ petioles } & & \multicolumn{2}{|c|}{ blades } & \multicolumn{3}{|c|}{ petioles } \\
\hline & $\mathrm{S}$ & $\mathrm{A}$ & mean & $\mathrm{S}$ & $\mathrm{A}$ & mean & $\mathrm{S}$ & A & mean & $\mathrm{S}$ & A & mean \\
\hline Lukullus & 0.37 & 0.25 & 0.31 & 0.35 & 0.26 & 0.30 & 5.54 & 5.96 & 5.75 & 6.17 & 7.78 & 6.97 \\
\hline Green White & 0.45 & 0.34 & 0.39 & 0.43 & 0.34 & 0.38 & 5.17 & 5.96 & 5.56 & 5.91 & 7.85 & 6.88 \\
\hline Ribbed & 0.45 & 0.26 & 0.36 & 0.35 & 0.28 & 0.31 & 5.69 & 6.24 & 5.97 & 6.41 & 8.43 & 7.42 \\
\hline Vulcan & 0.65 & 0.29 & 0.47 & 0.37 & 0.32 & 0.35 & 4.92 & 5.41 & 5.17 & 6.01 & 8.00 & 7.00 \\
\hline Bresanne & 0.61 & 0.27 & 0.44 & 0.38 & 0.32 & 0.35 & 4.90 & 5.35 & 5.12 & 6.09 & 7.72 & 6.90 \\
\hline \multicolumn{13}{|l|}{ Green Silver } \\
\hline Mean & 0.51 & 0.28 & 0.40 & 0.38 & 0.30 & 0.34 & 5.24 & 5.78 & 5.51 & 6.12 & 7.95 & 7.04 \\
\hline S - spring growi & & A- aut & Imn & & & & & & & & & \\
\hline \multicolumn{13}{|l|}{$\operatorname{LSD} \alpha=0.05$ for: } \\
\hline term of growing & & & 0.05 & & & 0.03 & & & 0.34 & & & 0.40 \\
\hline cultivar & & & 0.08 & & & 0.04 & & & 0.54 & & & n.s. \\
\hline interaction & & & 0.11 & & & n.s. & & & n.s. & & & n.s \\
\hline
\end{tabular}

Table 4. Calcium and magnesium content in Swiss chard in relation to cultivar and term of growing (mean for 2005-2007)

\begin{tabular}{|c|c|c|c|c|c|c|c|c|c|c|c|c|}
\hline \multirow{3}{*}{ Cultivar } & \multicolumn{6}{|c|}{ Calcium (\% d.m.) } & \multicolumn{6}{|c|}{ Magnesium $(\% \mathrm{~d} \cdot \mathrm{m})}$. \\
\hline & \multicolumn{3}{|c|}{ blades } & \multicolumn{2}{|c|}{ petioles } & \multicolumn{4}{|c|}{ blades } & \multicolumn{3}{|c|}{ petioles } \\
\hline & $\mathrm{S}$ & A & mean & $\mathrm{S}$ & A & mean & $\mathrm{S}$ & A & mean & $\mathrm{S}$ & A & mean \\
\hline Lukullus & 0.08 & 0.12 & 0.10 & 0.12 & 0.16 & 0.14 & 0.59 & 0.49 & 0.54 & 0.22 & 0.33 & 0.28 \\
\hline Green White Ribbed & 0.08 & 0.10 & 0.09 & 0.11 & 0.18 & 0.15 & 0.67 & 0.58 & 0.63 & 0.28 & 0.36 & 0.32 \\
\hline Vulcan & 0.06 & 0.10 & 0.08 & 0.13 & 0.18 & 0.16 & 0.63 & 0.52 & 0.57 & 0.27 & 0.36 & 0.31 \\
\hline Bresanne & 0.08 & 0.11 & 0.09 & 0.13 & 0.17 & 0.15 & 0.67 & 0.57 & 0.62 & 0.29 & 0.43 & 0.36 \\
\hline Green Silver & 0.08 & 0.11 & 0.09 & 0.12 & 0.16 & 0.14 & 0.67 & 0.56 & 0.61 & 0.27 & 0.40 & 0.33 \\
\hline Mean & 0.08 & 0.11 & 0.09 & 0.12 & 0.17 & 0.15 & 0.65 & 0.54 & 0.59 & 0.26 & 0.38 & 0.32 \\
\hline $\mathrm{S}$ - spring growing & \multicolumn{3}{|c|}{ A- autumn } & & & & & & & & & \\
\hline $\operatorname{LSD} \alpha=0.05$ for: & & & & & & & & & & & & \\
\hline term of growing & & & 0.01 & & & 0.01 & & & 0.03 & & & 0.02 \\
\hline cultivar & & & n.s. & & & n.s. & & & 0.04 & & & 0.03 \\
\hline interaction & & & n.s. & & & n.s. & & & n.s. & & & n.s. \\
\hline
\end{tabular}

